\title{
A REVISION OF THE WEST INDIAN RACES OF LOXIGILLA NOCTIS (LINNAEUS)
}

By StUART T. DANFORTH,

College of Agriculture and Mechanic Arts, University of Puerto Rico, Mayagüez, P. R.

Some confusion has existed for many years concerning the various races of Bullfinches (Loxigilla noctis) occurring in the West Indies. Therefore during recent collecting trips to the Lesser Antilles I have endeavoured to accumulate series from as many points as possible. In addition I have examined, measured, and made notes upon the entire series of these birds in the U. S. National Museum, the Field Museum of Natural History, the Museum of Comparative Zoölogy, the American Museum of Natural History, and the Academy of Natural Sciences of Philadelphia. Thanks to the courtesies of the authorities of these museums it has been possible to examine a total of 396 specimens, including examples from all the islands on which the species is known to exist, and the types of most of the forms which have been recognized. The measurements of all these specimens were personally taken, so all may be regarded as comparable.

Loxigilla is a typically West Indian genus, being represented by two species and a number of races in the Bahamas and Greater Antilles, and in the Lesser Antilles by the extinct $L$. grandis of St. Kitts, and by the various races of $L$. noctis and the closely allied $L$. barbadensis. The only form of Loxigilla lnown from outside the West Indies is Loxigilla noctis propinqua from Guiana, a form of which it has not been my privilege to examine specimens, and which is accordingly not included in this revision.

From the West Indies I have recognized nine races of Loxigilla noctis, in addition to the closely related species, Loxigilla barbadensis. Of these nine races one, Loxigilla noctis desiradensis, is described as new, another which has not generally been recognized, L.n. chazaliei, is considered as valid and the distribution of two others, L.n. ridgwayi and L.n. coryi, has been found to vary considerably from that which has been generally assigned to them.

All measurements in this paper are expressed in millimeters. 


\section{Loxigilla noctis coryi (Ridgway)}

Pyrrhulagra coryi RIDGWaY, Auk, 15, Oct. 1898, p. 323 (St. Eustatius, type in U.S. National Museum, No. 80965).

Subspecific characters: Adult male.-Entire plumage black, except a small superciliary stripe, chin, throat and under tail-coverts, which are chestnut-rufous, and the under wing-coverts, which are largely white; the bill, legs and feet are black, the soles of the feet being tinged with light grayish; iris dark brown. Adult female.--Upper surface dull grayish olive brown, the wings and tail fuscous, the primaries being slightly edged with grayish olive, and the greater wing-coverts broadly edged with cinnamon rufous; underparts deep olive gray, frequently more or less suffused with brownish; under tail-coverts light cinnamon; bill with the upper mandible dusky, the lower dark horn color; legs and feet slate gray, claws dusky, soles of feet tinged with yellow, iris dark brown. Immature male.-Similar in color to the adult female, but larger.

Measurements: Adult male.-5 speeimens from Anguilla, wing 64.9-66.8 (65.82); tail 48.9-50.1 (49.80); culmen from base 14.7-15.8 (15.24); tarsus 18.9-19.5 (19.28). 1 specimen from St. Martin, wing 65.6; tail 54.5; culmen from base 15.0 ; tarsus 13.0. 1 specimen from Saba, wing 66.0 ; tail 48.0 ; tarsus 19.6; culmen from base 14.9. 8 specimens from St. Eustatius, wing $63.5-67.6$ (65.35); tail 50.0-56.5 (53.10); culmen from base 15.3-17.0 (15.87); tarsus 18.8-19.8 (19.36). 24 specimens from St. Kitts, wing 65.0-69.4 (66.70); tail 48.8-54.3 (51.19); culmen from base 14.4-16.9 (15.76); tarsus 17.0-21.5 (19.54). 3 specimens from Nevis, wing $68.0-70.6$ (69.20); tail 51.3-56.6 (54.57); culmen from base, 15.2-16.2 (15.80); tarsus 17.4-21.5 (18.83). Female. 2 specimens from Anguilla, wing 62.0-64.1 (63.05); tail 47.5-47.6 (47.55); culmen from base 14.0-14.5 (14.25); tarsus 18.0-18.5 (18.25). 1 specimen from Saba, wing 63.7 ; tail 47.6 ; tarsus 19.6 ; culmen from base 14.8. 5 specimens from St. Eustatius, wing $62.0-65.8$ (63.72); tail $46.3-49.0$ (47.82); culmen from base 14.6-15.4 (14.92); tarsus 18.7-19.7 (19.30). 6 specimens from St. Kitts, wing 63.9-65.5 (64.43); tail 48.4-52.3 (49.38); culmen from base 15.0-16.0 (15.57); tarsus 18.9-20.0 (19.25). Immature male. 2 specimens from Anguilla, wing 63.5-64.2 (63.85); tail 46.2-49.2 (47.70); eulmen from base 14.7-15.2 (14.95); tarsus 18.8-19.0 (18.90). 5 specimens from St. Eustatius, wing (average of 4) 64.0-67.3 (66.32); tail 47.3-49.8 (48.42); culmen from base 15.4-16.2 (15.82); tarsus 19.1-20.6 (19.94). 6 specimens from St. Kitts, wing 63.9-65.5 (64.43); tail 48.4-52.3 (49.38); culmen from base 15.0-16.0 (15.57); tarsus 18.9-20.0 (19.25). Immature Female. 1 specimen from St. Kitts, wing 61.8 ; tail 43.8 ; culmen from base 15.2 ; tarsus 18.0 .

Range: Anguilla, St. Martin, Saba, St. Eustatius, St. Kitts, Nevis.

SPecimens examined: Anguilla 9; St. Martin 1; Saba 2; St. Eustatius 18; St. Kitts 45; Nevis 3.

Remarks: Two adult males from Anguilla may be matched perfectly in color by St. Kitts birds. The other three are much lighter, but do not appear to be fully adult. I have a specimen 
from St. Eitts in similar light plumage with a few dark feathers beginning to appear, indicating that the males when assuming the adult plimage attain red feathers on the throat before losing the body feathers of the immature plumage. Fully adult males from all these islands are much darker in color than those from Barbuda and Antigua. The single specimen from St. Martin agrees well in color with the series from St. Eustatius, and there is no doubt that the birds from these northern islands shonld be regarded as coryi instead of as ridguayi, under which name they have hitherto been listed.

Birds from Nevis agree well with those from St. Kitts in color, but they average considerably larger and may represent a new subspecies, but unless further material corroborates this difference it seems best to regard the Nevis birds as coryi.

Apparently this bird sometimes breeds before attaining fully adult plumage, as a male just beginning to show red on the throat collected at Friar's Bay, St. Kitts on June 25, 1935 had its testes so enlarged as to indicate breeding.

\section{Loxigilla noctis chazaliei Oustalet}

Loxigilla Chazaliei Oustarem, Bulletin de la Société Zoologique de France, 20, 1895, p. 184. (Barbuda, collected by Count Dalmas, type: probably in the Paris Museum.)

Subspecific characters: Similar in coloration to $L$. $n$. coryi, but the adult males are much lighter in color and smaller in size. They resemble $L$. $n$. ridgwayi most closely, but are smaller and lighter than that form. The under tail-coverts are chestnut-rufous. The immature males are of a lighter, more yellowish brown color above than those of any other form.

Measurements: Adult male. 5 specimens from Barbuda, wing 64.0-66.3 (64.84); tail (average of 4) 50.00-50.7 (50.30); culmen from base 14.5-15.5 (15.16); tarsus $17.3-21.0$ (18.68). Female. 3 specimens from Barbuda, wing 61.8-68.9 (65.32); tail 45.0-53.5 (49.63); culmen from base 14.5-16.5 (15.53); tarsus 17.9-20.0 (18.96). Immature male. 3 specimens from Barbuda, wing $58.7-62.5$ (60.73); tail 49.4-50.0 (49.67); culmen from base 15.0-15.7 (15.33); tarsus $16.5-19.4(18.10)$.

Range: Restricted to the Island of Barbuda.

Specimens examined: Barbuda, 11.

Remarlis: This is the lighest colored and the smallest of all the West Indian races of $L$. noctis. L.n. ridgwayi of Antigua is the form which most closely approaches it, but that is slightly larger and noticeably darker. The difference in eolor is even more noticeable in the field than in the museum, but even there the darkest Barbuda 
bird was found to be lighter than the lightest Antigua bird, clearly demonstrating this to be a distinct and valid race.

Loxigilla noctis ridgway (Cory), Cat. W. Ind. Birds, 1892, p. 15, 112, 150, part. (Antigua, type in Field Museum, No. 9059, collected May 2, 1890 by C. S. Winch).

Subspecific characters: Similar to $L$. n. coryi, but decidedly lighter, the adult male being grayish black instead of pure black; the females and immature males are also paler. More similar to $L$. $n$. chazaliei, but larger and somewhat darker.

Measurements: Adult male. 14 specimens from Antigua, wing 61.6-67.8 (65.69); tail 48.5-53.2 (51.56); culmen from base 14.8:16.1 (15.31); tarsus 17.3-20.0 (18.27). Female. 2 specimens from Antigua, wing 59.6-66.3 (62.95); tail 50.5-51.4 (50.95); culmen from base 15.0-15.3 (15.15); tarsus 17.5-19.2 (18.35). Immature male. 2 specimens from Antigua, wing 63.5-63.7 (63.60); tail 51.0-51.6 (51.30); eulmen from base 15.2-16.1 (15.65); tarsus 18.318.5 (18.40).

Range: Restricted to the Island of Antigua.

Specimens examined: Antigua, 18.

Remarks: Decidedly the lightest of all the West Indian races of L. noctis except $L$. n. chazaliei, than which it is somewhat darker and slightly larger.

\section{Loxigilla noctis dominicana (Ridgway)}

Pyrrhulagra dominicana, RIDGWax, Auk, 15, Oct. 1898, p. 323 (Dominica, type in U. S. National Museum, No. 77829 , collected by F. A. Ober at Mt. Lake, 2,500 feet altitude).

Subspecific characters: Similar to $L$. n. coryi, but much larger, and averaging darker, the adult males being consistently of a deep black color, with the under tail-coverts rufous or largely rufous. The females are also darker and more tinged with rufous above.

Measurements: Adubt male. 18 specimens from Guadeloupe and Grande Terre, wing 67.2-74.3 (71.01); tail 49.0-57.2 (52.94); culmen from base 15.016.7 (15.61); tarsus 19.0-20.9 (20.16). 2 specimens from Marie Galante, wing 71.9-72.3 (72.10); tail 55.0-56.7 (55.85); culmen from base 14.8-15.3 (15.05); tarsus 17.6-20.0 (18.80). 12 specimens from Dominica, wing 71.4-75.3 (73.64); tail 52.7-60.0 (54.85); culmen from base 15.0-17.1 (15.77); tarsus 18.0-20.9 (20.03). Female. 1 specimen from Montserrat, wing 66.0 ; tail 47.3 ; culmen from base 15.7; tarsus 20.5. 24 specimens from Guadeloupe and Grande Terre, wing (average of 23) 64.0-70.1 (66.61); tail 46.3-52.3 (49.43); culmen from base (average of 20) 14.5-16.3 (15.26); tarsus (average of 22) 17.6-20.7 (19.25). 1 specimen from Marie Galante, wing 65.3; tail 48.4; culmen from base 15.0; tarsus 19.4. 10 specimens from Dominica, wing (average of 8) 64.8-70.3 (67.74); tail (average of 9), 45.3-51.0 (48.33); culmen from base (average of 9) 14.4-20.5 (16.28); tarsus 18.7-21.0 (19.98). Immature male. 3 specimens from Guadeloupe and Grande Terre, wing 66.7-67.9 (67.23); tail 47.2-49.0 (48.23); culmen from base 14.8-15.8 (15.20); tarsus 18.9-19.1 $(19.00)$. 2 specimens from Dominica, wing $68.9-69.0$ (68.95); tail $46.0-48.7$ (47.35); culmen from base 15.7-16.8 (16.25); tarsus 19.9-20.8 (20.35). 
Range: Guadeloupe and Grande Terre, Marie Galante, Dominica and probably Montserrat.

Specimens examined: Guadeloupe and Grande Terre 45; Marie Galante 3; Dominica 24; Montserrat 1.

Remarks: This is a very large and dark form, the largest of all the races of $L$. noctis. Specimens from Dominica average somewhat larger than those from the other islands particularly in the wing measurements, but these differences seem too slight to warrant subspecific recognition. No constant differences in color can be noted. As I have seen but one specimen (a female) from Montserrat, I am including that island doubtfully in the range of this race, although the specimen in question agrees fairly well with examples from Guadeloupe, and is probably referable to this form.

\section{Loxigilla noctis desiradensis subsp. nov.}

Type: Coll. Field Museum No. 23676, adult male, Desirade, March 7, 1886, collected by W. B. Richardson.

Subspecific characters: Similar to $L$. n. dominicana in color, but with shorter wing and tarsus.

Measurements: Adult male. 4 specimens from Desirade, wing 67.3-69.6 (68.35); tail 48.1-59.4 (54.60); culmen from base 15.5-15.9 (15.62); tarsus 17.4-20.0 (18.15). The type measures wing 68.0 ; tail 59.4 ; eulmen from base 15.5; tarsus 17.4. Adult female. 2 specimens from Desirade, wing 62.0-65.5 (63.75); tail 47.0-49.2 (48.10); culmen from base 14.8-15.7 (15.25); tarsus 17.9-18.4 (18.15).

Range: Island of Desirade, near Guadeloupe.

Specimens examined: Desirade 6.

Remarks: This form is most closely related to L.n. Dominicana, but the wing and tarsus average decidedly shorter. In dominicana these average 72.06 and 20.02 respectively for adult males and 66.82 and 19.36 for females. Thus the wing of desiradensis averages 3.71 millimeters shorter in males and 3.07 millimeters shorter in females, while the tarsus averages 1.87 millimeters shorter in males and 1.21 in females.

\section{Loxigilla noctis noctis (Linnaeus)}

[Fringilla] noctis Linnaeus, Syst. Nat., ed. 12, 1, 1766, p. 320 ("Jamaica", "Mexico", Martinique).

Subspecific characters: Similar in coloration to $L$. $n$. dominicana, but the adult males with the under tail-coverts chiefly black, sometimes with a little admixture of rufous or chestnut, and averaging very slightly smaller, while the females are lighter and less tinged with rufous above. 
Measurements: Adult male. 20 specimens from Martinique, wing 67.0 73.0 (71.33); tail 49.7-54.1 (52.84); culmen from base 14.6-16.0 (15.33); tarsus 18.1-21.0 (19.65). Female. 5 specimens from Martinique, wing 65.668.8 (67.00); tail (average of 4) 48.6-52.0 (50.40); culmen from base 14.516.5 (15.40); tarsus (average of 2) 17.3-19.1 (18.20). Immature male. 1. specimen from Martinique, wing 67.9 ; tail 51.3 ; culmen from base 16.6 ; tarsus 19.3 .

\section{Range: Island of Martinique.}

Specimens examined: Martinique 26.

Remarks: The adult males are quite similar to L.n. dominicana, differing chiefly in the small amount of rufous in the under tailcoverts. The females are lighter and less tinged with rufous above than those of dominicana, but darker and less olive than those of L.n. sclateri, being intermediate between the two, but very distinct from either.

\section{Loxigilla noctis sclateri Allen}

Loxigilla noctis sclateri. Allen, Bull. Nutt. Orn. Club, v, July 1880, p. 166 (St. Lucia, type in Museum of Comp. Zoöl., collected by John Semper, no date on label).

Subspecific characters: Adult males are similar in coloration to those of L. n. noctis; females and immature males are much lighter in color, being light olive above, and also lighter below; both sexes are smaller.

Measurements: Adult male. 45 specimens from St. Lucia, wing 65.8-71.6 (68.85); tail 46.3-55.0 (50.56); culmen from base 13.7-15.9 (14.74); tarsus (average of 4), 18.0-19.9 (18.92). Female. 15 specimens from St. Lucia, wing (average of 14) 62.8-67.9 (64.84); tail (average of 14) 44.5-52.6 (47.36); culmen from base 14.0-15.0 (14.52); tarsus 17.0-20.7 (18.75). Immature male. 2 specimens from St. Lucia, wing 64.5-64.6 (64.55); tail 44.046.0 (45.00); tarsus 18.7-19.6 (19.15); culmen from base 14.5-15.0 (14.75).

Range: Island of St. Lucia.

Specimens examined: St. Lucia 78 (including 16 unsexed birds measurements of which are not included).

Remarks: This form differs from L.n. noctis chiefly in its smaller size and the lighter coloration of the females and immature males, which are lighter than those of any other race with the exception of L.n. ridgwayi and L.n. chazaliei.

\section{Loxigilla noctis crissalis (Ridgway)}

Pyrrhulagra crissalis Ridgway, Auk, XV, Oct. 1898, p. 323 Cumberland Valley, St. Vincent, type in U. S. National Museum, No. 74083, collected Oct. 22, 1877 by F. A. Ober). 
Subspecific characters: Similar to $L$. n. dominicensis, but slightly smaller, and the adult males are even deeper black; the chesuut-rufous area on the throat is more extensive, extending to the anterior portion of the chest; under tail-coverts rufous; females and immature males similar to those of $L$. $n$. noctis, but somewhat lighter, especially below.

Mreasurements: Aault male. 16 specimens from St. Vineent, wing 67.9$72.5(70.05)$; tail (average of 15) 48.7:54.0 (50.57); culmen from base 14.4-16.5 (15.64); tarsus 17.8-20.5 (18.94). Female. 7 specimens from St. Vincent, wing (average of 5) 67.0-69.0 (67.98); tail (average of 5) 46.651.5 (49.00); culmen from base 14.4-15.6 (15.13); tarsus 18.0-20.4 (18.77). Immature male, 6 specimens from St. Vincent, wing 65.6-69.0 (67.11); tail 46.0-48.7 (47.40); eulmen from base $15.6-16.1$ (15.91); tarsus 18.3-19.9 (19.31).

Range: Island of St. Vincent.

Specimens examined: St. Vincent 29.

Remarks: This form, although very distinet, is most closely allied to L.n. grenadensis of Grenada, and may be distinguished by the characters mentioned under that species.

\section{Loxigilla noctis grenadensis (Cory)}

Pyrrhulagra noctis grenadensis ConY. Cat. W. Ind. Birds, 1892, p. 16, 112, 150, part (Grenada, type in Field Museum, No. 9041, without data, collected by J. G. Wells).

Subspecific characters: Similar to $L$. $n$. crissalis, but smaller; the adult males with the throat patch mueh more restricted and of a darker rufous color (with less of an orange tinge); under tail-coverts rufous, sometimes with admixture of black; the females are less olivaceous (more washed with brownisly) above. The adult male has the iris dark brown; upper mandible dusky, the lower dark horn color; legs and feet slate gray, claws dusky, soles, tinged with yellow.

Measurements: Adult male. 38 specimens from Grenada, wing (average of 37) 65.3-70.1 (67.91); tail 45.5-53.0 (49.00); culmen from base (average of 36) $14.5: 16.0$ (15.23); tarsus (average of 37) 18.0-20.6 (19.25). Female. 12 specimens from Grenada, wing 62.5-66.8 (64.25); tail (average of 11) $44.0-49.3$ (46.72); culmen from base 13.6-15.4 (14.39); tarsus 17.5-20.6 (18.62).

\section{Range: Island of Grenada.}

Specimens examined: Grenada 53 (including 3 unsexed specimens not measured).

Remarks:- This race resembles L.n. sclateri of St. Lucia in size and color more closely than L.n. crissalis of St. Vincent, with which form it has been proposed to unite it. The characteristics separating the latter two forms have been given under the subspecific characters. It may be noted that the type of grenadensis is an exceptionally dark 
bird, darker than any other specimens examined from Grenada. It may not be out of place to mention here that, although this bird was formerly one of the most abundant birds in Grenada, it has now become decidedly scarce.

\section{Loxigilla barbadensis Cory}

Loxigilla barbadensis CoRY, Auk, 3, July 1886, p. 382 (Barbados, type in Field Museum, No. 9047, collected February 4, 1886 by W. B. Richardson).

Specific characters: Similar in all stages to the female and immature stages of the lighter colored forms of $L$. noctis, being intermediate in color between $L$. n. sclateri and, L. n. ridgwayi, but lacking the buffy or rusty tinge on the sides of the head and other parts, which is present in all forms of L. noctis.

Measurements: Adult male. 13 specimens from Barbados, wing (average of 11) 67.7-71.0 (69.29); tail (average of 11) 48.0-51.4 (49.93); culmen from base 14.9-16.5 (15.81); tarsus 18.1-21.5 (19.65). Female. 10 specimens from Barbados, wing (average of 8) 65.8-73.3 (69.74); tail (average of 8) 47.5-53.2 (50.15); culmen from base (average of 9) 14.9-15.8 (15.39); tarsus 18.1-20.5 (19.30). Immature male. 1 specimen from Barbados, wing 64.0 ; tail 45.0 ; culmen from base 14.4; tarsus 17.3 .

Range: Island of Barbados.

Specimens examined: Barbados 24.

Remarks: This spocies is very closely allied to L. noctis and was in all probability derived from it. It differs from all forms of L. noctis in that the adult male never assumes the characteristic black and rufos plumage of that species, remaining in a plumage indistinguishable from that of the female. It greatly resembles the female and immature male of the lighter races of $L$. noctis. 